\section{動物実験 と実験動物}

\section{I}

野 村 達 次

財団法人 実験動物中央研究所

\section{1. はじめに}

生物科学に和ける特有な研究方法である動物実験は, 近年いちじるしく進歩してきた。これは，新しい学問分 野である実験動物科学 (Laboratory Animal Science) の発展によって，実験動物の質の向上，ならびに動物実 験方法の開発・改良の成果に負うところが大きい。

医学・生物学研究領域に招いて, 化学的あるい性理 学的測定を行なら場合，その目的に応じて試薬・溶㓮の 種類や純度, あるいは測定機器類の精度・種類の選択を 行ない，さらに実験方法についても検討されている。こ れらの吟味は，再現性と信頼性のある実験成績をうるた めの配慮である.

動物実験に拉いては，動物に実験処置を加え，動物自 身の反応を観察したり，あるいはその反応をひとつの尺 度として読みとる場合が多い，この意味から，動物実験 飞使用される動物は，“生きた試薬”であり，“生きた測 定器”であるといえる，したがって，使用する動物の種 類, あるいは質の吟味, 実験中の飼育条件や実験条件の 検討をしなければならない。しかし，使用される試薬， あるいは測定器となるものが “生さもの”であるところ 飞，実験成績の再現性・信頼性をらることのむずかしさ， 複雑さがある。

本講座では，動物を実験につかう場合に，実験動物に ついて知って和かなければならないと思われる基本的な 問題のいくつかをとりあげてみたい。

\section{2. 実験動物の分類}

最初に，実験に使用される動物をいろいろの観点から 分類し, 同時に, 実験動物科学の分野でしばしば使用さ れる用語について説明を加える。

\section{a. 実験動物の使用目的による分類}

实験に使用されている動物は，実験目的が多岐にわた るため，種類も多く，用途も多方面にわたっている。乙 かし，それらを使用目的によって，

1) 研究用

2）㭘定用

3) 原材料用

に分けることができる(3)（図 1)。実験に使用される動 物を，この3つの用途に明確に区分することは必ずしも 可能ではなく，2つ以上の区分にまたがって使用される こともあるが，一般にはこのような分けかたをすること ができよう。

「研究用の動物」とは，動物の生物反応そのものを研 究対象とする場合の動物である。たと党ば，マウスにメ チルコラントレンを投与して，発癌の機序をみるとか， 動物を異常温度環境下に暴露して,それらの生理機能の 变化を観察し，体温調節のメカニズムを追究するような， 動物の生命現象や生物反応々のものを調べることを目的 として，実験に供される動物である.

1. 研究用：動物の生命現象，生物反応そのものをしらべる，

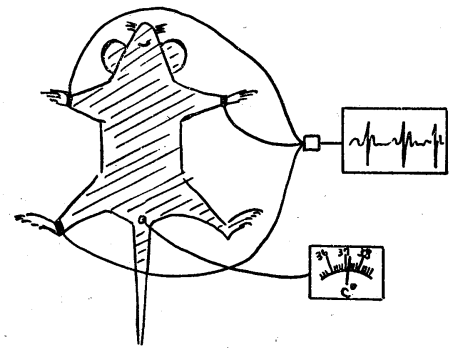

2. 検定用：動物の反応が 1 つのスケールとなる.

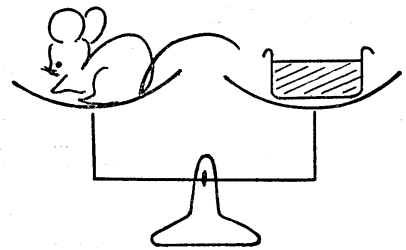

3. 原材料用：動物からの材料が研究（検定，擎造）飞必要

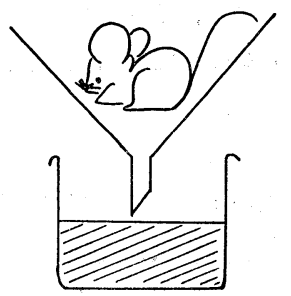

UIIIII, ‥研究対象

図１動物の使われ方（使用区分）（近藤恭司） 


\section{表 1 実験動物の使用区分}

\begin{tabular}{lcccc}
\hline 動 物 名 & $\begin{array}{c}\text { 研究用 } \\
(\%)\end{array}$ & $\begin{array}{c}\text { 検定用* } \\
(\%)\end{array}$ & $\begin{array}{c}\text { 原材料用 } \\
(\%)\end{array}$ & $\begin{array}{c}\text { その他 } \\
(\%)\end{array}$ \\
\hline マウス & 43 & 28 & 28 & + \\
ラット & 74 & 24 & - & + \\
モルモット & 48 & 48 & $2 \sim 3$ & + \\
ウサギ & 56 & 36 & + & + \\
イ ヌ & 90 & + & + & + \\
ネ & 81 & 17 & - & + \\
ハムスター & 89 & $6 \sim 10$ & - & + \\
フェレット & 12 & 21 & 65 & + \\
サル & 19 & 5 & 75 & + \\
ヒツジ・ヤギ & 48 & $4 \sim 5$ & 38 & $8 \sim 10$ \\
ウシ・ウマ・ブタ & 48 & 18 & + & + \\
ニワトリ & 79 & + & 95 & - \\
鷄 卵 & $3 \sim 4$ & + & - & + \\
ハト・ウズラ & 39 & 61 & - \\
アヒル・十姉妹 & 39 & & & + \\
\hline
\end{tabular}

* 検定用というのは, 日本医学会調査の診断用を含む. 「その他」は教育など

十：わずかにあり，一：ほとんどなし

（日本に打ける動物実験の現状，1960，日本医学会より算出）

「検定用の動物」は，動物の反応がひとつの尺度とし て利用されるときの動物である、ホルモンの Bioassay (単位) とか，薬物の毒性検査(致死量)，ワクチンの効 力検定（力価）などに使われる動物がこれである．この 場合には，直接研究の対象となっているものは，ホルモ ン・薬物・ワクチンなどである．動物の生物反応々のも のは, 研究対象とされるのではなく, 生物反応がひとつ の尺度として利用されているのである。

「原材料用の動物」とは，動物からとりだされた物質， または動物体の一部分が，研究の材料となる場合の動物 をいう，これには，免疫血清をつくるウサギ，補体を必 要とするときのモルモット，小児麻㾝ウイルス培養用の サルの腎臓，細菌培養のための新鮮血液，などをうるた めの動物がある。これらのほかに，ワクチン製造用とし て使われる動物る，広い意味での原材料用動物と考える ことができる。

1960 年に, 日本医学会が行なった「日本に淤ける動 物実験の現状調查」(5) の結果から，各種の動物の使用区 別の割合を算出したものを表 1 に示してある。これによ ると, マウスでは, 研究用・検定用・原材料用に平均し て使用されているのに対し，イヌ・ネコ・ハムスターな ぞは研究用に，サル・タマゴなどは原材料用に多く使用 されていることがわかる。

\section{b . 実験動物の開発・改良・純化の程度による分類}

実験に使用されている動物は, 実験動物としての開 発・改良・純化の程度によって，つぎのように分けるこ とができる(10).
1) 野生動物

2）いわゆる家畜

3）実験動物

4）純化された実験動物

「野生動物」を捕獲して実験に使っている例としては, サルや变温動物などがある．現在，実験に使われている サルの大部分である Macaca 属(カニクイザル・アカゲ ザル）は，東南アジア・インド地区で捕獲され，輸入さ れたサルであり，それらの素性や健康状態についてはま ったく明らかでなく，実験前に，ある程度の検疫・馴化 はされてはいるが, 遺伝統御・環境統御・微生物統御な ぞの実験動物化のための統御はほとんどなされていない。 しかし，人為的統御がまったくなされていない捕獲野生 動物であっても，実験目的によっては不可欠な動物であ る場合が多い。

つぎに「いわゆる家畜」から流用して実験に使用し ている例もきわめて多い、しかし，家畜は，ウシ・ブタ・ ニワトリのように，乳・肉・卵・皮革などをうるための 産業的目的で育成されるか，あるいは，イヌ・ネコのよ うに愛がん用, あるいは防犯用・盲導用などとして, 社 会的目的で改良・繁殖されたものである．産業上，ある いは社会上の必要から飼いならされた家畜の改良の方向。 またはそれらの飼育方法は，実験動物として求められる ものとは違っている。たとえば，家畜は食肉用として大 きく育つように改良されているし，飼料は病気の発生を 予防するために抗生物質が添加されている。このように， 産業上有効な手段も，実験動物にとってはかえって邪魔 になることがある。

「実験動物」は，“研究上重要であるとして飼いならさ れ，合目的に育成・繁殖・生産された動物”である。こ

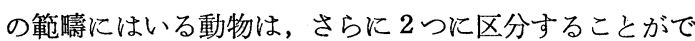
きる. その第 1 は, マウス・ラット・モルモットのよう に, 古くから研究用の動物として開発・改良が進められ てきた動物である。これらの動物は，すでに充分に飼い ならされ，その繁殖・生産方法も確立され，現在では， 多くの実験目的に応じて，改良されつつある.

第 2 は，野生動物から実験動物化への方向を目指して， 人為的飼育・繁殖が進められている動物である. 第 2 次 大戦後, 医学・生物学の急速な発展にともない, 実験が 多岐にわたるようになったため，実験に必要とされる動 物も多様化し，「野生動物」あるいは「いわゆる家畜」 に，実験動物として必要な統御を加える “実験動物化” が急速に進められている。これらの例としては，実験室 などで人工的に繁殖さ礼ている，サル・イヌ・ウズラ。 
カエル・イエバエなどがある。

「純化された実験動物」とは，動物実験の精度を高め るために，現存の「実験動物」にさらに科学的に手を加 え，実験目的と実験精度に合致するように生産された動 物である．現在の実験動物の純化の方向の中心は，遺伝 的純化之微生物的純化であろう。

遺伝的純化とは，実験処置に対する反応の差が見いだ しやすいような，さらに実験成績の分析を容易にするよ うな，遺伝的構成をもつ動物を作製することである．こ の目的のために，すでに多数の近交系が育成されている.

微生物的純化とは，実験成績に影響を沶よぽす環境因 子のひとつである，微生物因子についての統御がなされ た動物を作製することである.動物体に潜在する病原微 生物を排除することや，消化管内の非病原微生物を規制 することによって，動物実験成績の再現性をさまたげる 影響をなくすことを目的としている。

\section{c . 遺伝統御の方法による分類}

実験に使用される動物は，遺伝的統御の方法によって， つぎのように分けることがでさる(4,6).

1) 近交系

2)ミュータント系

3) クローズド・コロニー

4) 交雑 群

5) Mongrel

「近交系」は，“兄妹交配または親子交配を20 代以上 継続している系統”と定義されている。「近交系」は， 個体間（同一系統内）での遺伝的変異をできるだけ少な くし，さらに，異なる系統との間の遺伝的差異をできる だけ見いだしやすいように作製されたものである．現在， マウスでは A, BALB/c, C3H/He, C57BL/6J など 200 系以上の「近交系」が作製され，それぞれの特徵が調査 されている。

「ミュータント系」は，“遺伝子記号をもって示しらる ような遺伝子型をその系統の特性としている系統，およ び遺伝子記号を明示しえなくとも淘汰選抜によって特定 の遺伝形質を維持することのできる系統” と定義されて いる.「ミュータント系」は, 以前は主として, $p$ (PinkEyed Dilution), $h r$ (Hairless), $d y$ (Dystrophia Muscularis) などの形態的特徵（毛色・眼色・被毛の有 無・尾の異常など）に限られていたが，最近では，酵素 活性 Es (Serum Esterase) ・ヘモグロビンタイプ $H b$ (Hemoglobin) - 免疫能 Ig (Immunoglobrin) などの, 生化学的 ・免疫学的な特徵が多数発見されている(1).
「クローズド・コロニー」は，“他の集団から移入がな く, 一定の集団内のみで繁殖され保有されている群”之 定義されている.「クローズド・コロニー」は「近交系」 とは異なり, ある程度の個体間の遺伝的変異はあると予 想されるが，何匹かを群にして扱った場合には，群間の 差ができるだけ少なくなるよらに維持されている。「ク ローズド・コロニー」は大量生産が可能であることが特 徵で, 検定用動物として広く使用されている. ddN, ICR マウスなどは「クローズド・コロニー」である。

「交雑群」は, “系統間の雑種” と定義されている. 「交雑群」の動物は, いわゆる雑種の動物とは異なり, そ の遺伝的素性は明らかで, 実験動物として比較的高い精 度をもつものである．現在では， $\mathrm{C} 57 \mathrm{BL} / 6 \mathrm{~J}$ と $\mathrm{DBA} / 2$ の交雑によってできた F 1(BDF 1) が，ガン研究・放射 線研究などの一部で使用されているにすぎないが，今後， 実験動物として大きな役割をもつものであろう.

「Mongrel」は，遺伝的統御のまったくなされていな い動物をいう．野生動物や，いわゆる野犬などがこれで ある・

\section{d・ 微生物統御の程度による分類}

実験動物の微生物統御とは, 動物を生産・維持するさ いに，外来微生物と動物との接触をできるかぎり規制す ることである．実験動物を微生物学的にみた質の程度に よる分類と, それらの動物のつくりかたによる分類との 関連はつぎのようになる ${ }^{(2,4,9)}$.
動物の微生物学的質の程度

1) 無菌動物

2) Gnotobiotes

3) SPF 動物
4) Conventional 動物
生産・維持方式

\}隔離方式 (Isolator system)

閉鎖方式 (Barrier system)

開 放 式 (Open system)
「無菌動物」とは, 分婏直前の母獣から帝王切開, ま たは子宮切断術によって無菌的にとりだした胎仔を，ビ ニールアイソレータ（図 2)，あるいはスチールタンクな どの無菌環境で飼育した動物である.なぜ, 帝王切開に よって胎仔をとりだすかといらと，らつらの細菌は胎盤 を通過しないので, 分婏直前の胎仔をとりだして無菌環 境で飼育した動物には，検出可能な微生物は証明されな い. 無菌動物の飼育方法は, 図 3 (上段) に示すような Isolator system（隔離方式）がとられ，空気は箃重な 濾過フィルターを通して室内に送風され，逆流防止の施 された排気トラップの消毒液槽をとおして外部に排出さ れる。アイソレータ内に入れる器具・器材は, あらかじ 


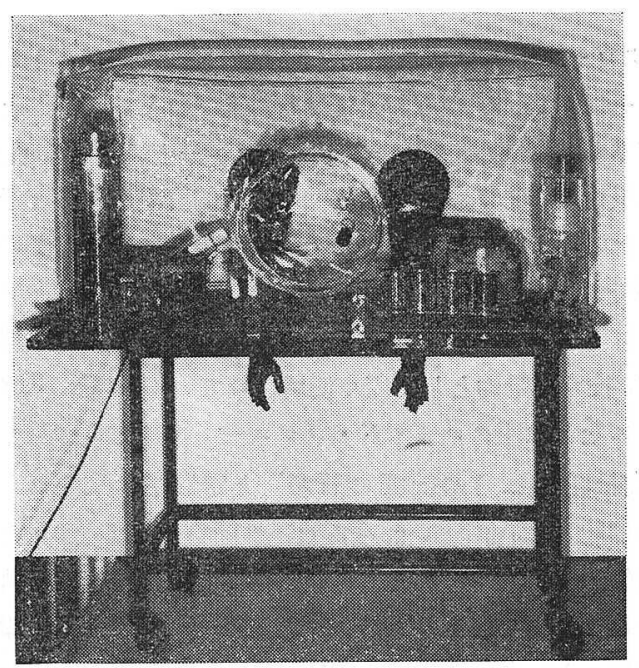

図 2 ビニールアイソレータ

好完全に隇菌したうえで，ステリールロックを介して中 に入れられる.動物の管理は, アイソレータに付属する 手袋を使用して行なわれるので, 人と動物との接触は完 全に隔絶していることになる.

「Gnotobiotes」は，“气の体にもっている微生物が明 確に知られている動物”之定義されている. Gnotobiotes は，無菌動物の消化管内に，明磼に同定された微生物を 定着させ, 無菌動物と同じ維持方式, Isolator system で飼育されている，無菌動物もGnotobiotes の簌疇には いるが，一般には，1種以上の微生物が存在する動物を Gnotobiotes とよんでいる.

「SPF (Specific Pathogen Free) 動物」は，帝王切開 由来の動物を, 図 3 (中段) の Barrier system の飼育 室で飼育した動物である. Barrier system では完全な 無菌環境を維持できないので,この種の動物は自然定着 した細菌丵を保有する。帝王切開により病原体を排除し たうえで, Barrier system で維持することにより，生 後は, 外来微生物感染の機会を極力少なくし，ふつらに みられる感染の多くのものが排除されている，之考光る わけである. Barrier system による飼育室への空気の 送りこみ, 器具・器材のとりいれ，についての基本的考 えかたは，無菌動物の場合と同様である。しかし，異な る点は, SPF 動物の飼育管理にあたっては, 飼育技術者 が飼育室内にはいって作業をするので, 人と動物が直接 接触するといらことである. 飼育技術者は, シャワーで 全身を洗い，隇菌した作業着・帽子・マスク・靴をつけ て作業をする。この方法ですれば，飼育室で大量の動物 の生産あるいは動物実験が行なえる利点がある。しかし， 飼育室が大きいために，無茵動物を飼育するIsolator

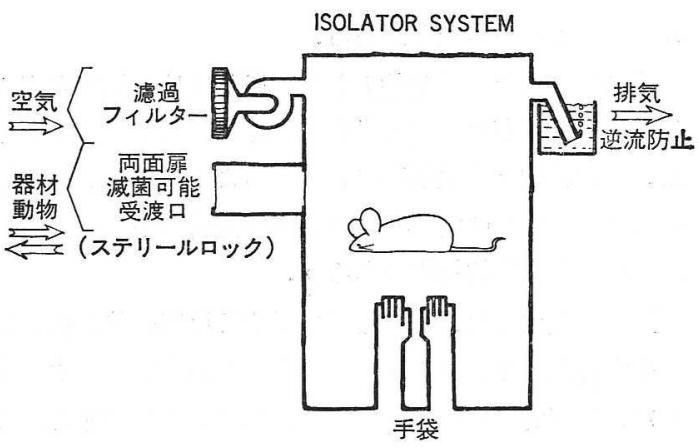

BARRIER SYSTEM

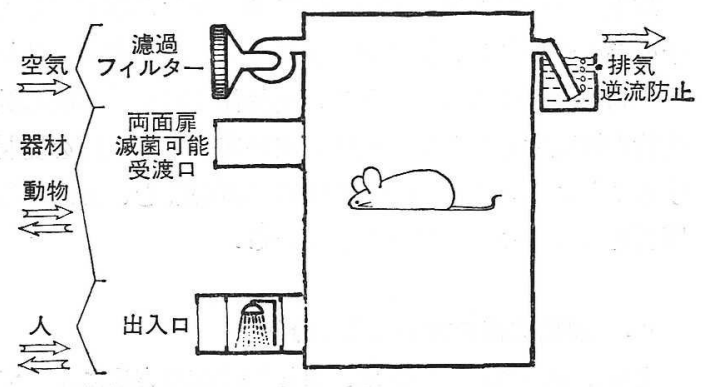

OPEN SYSTEM

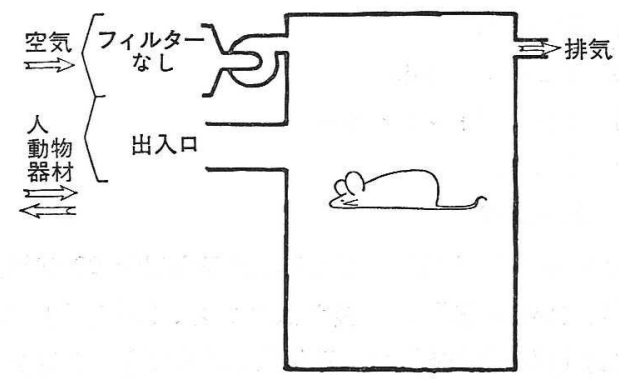

図 3 実験動物の飼育方法 (W.Heine 1964)

system に括けるような敛重な無菌状態を保持すること はむずかしい。

「Conventiona1 動物」は, 通常の動物といら意味であ る. 帝王切開由来の動物ではなく，また微生物統御が行 なわれていない動物である。この Conventional という 言葉は，前述の SPF 動物と区別するためにつかわれて いる. 現在, 市販されている動物の大部分は, この部類 に属する.この種の動物の飼育方法は, 一般に, 図 3 (下段)のような Open system である.

\section{3. 動物実験成績の現われかたと実験動物の 生理的均質性}

動物実験とは，一群の動物にある処置を加えて，これ に対する生理的反応，あるいは行動的反応をみることで 
ある.したがって, 理化学的測定の場合と同様, 一定の 処置に対する反応がつねに同一であるような, 実験条件 を見いださなければならない。

動物は，たとえばマウスであっても，その系統・性別・ 年令の違いによって, あるいは発育環境の違いによって も, 同一実験処置に対する反応は, 必ずしも一定ではな い.また，実験を行ならさいの環境の違いによっても， 反応は違ってくることがある.ここでは，「動物実験成 績の現われかた」について考えてみよう(7,8)（図 4).

動物は，両親からうけついだ多数の遺伝子をもった受 精卵から始をる。その個体を遺伝子からみた場合，これ を「遺伝子型 Genotype」とよんでいる. 遺伝子の作用 に発育環境，たとえば，卵管内・着床前後の子宮内の環 境, 胎盤での物質代謝, 泌乳など, 成熟するまでの発育 環境に和ける諸因子の作用が加わって, 外部に現われた 形質——形態的, あるいは永続的な生理機能——もっ た個体となる。これを「表現型Phenotype」とんでい る. 形態的，あるいは永続的な生理機能とは，たとえば， 毛色・骨格, あるいは各種酵素の違い, なぞで, これら は動物の種, あるいは系統によって, それぞれ特有なる のである.この表現型の決定に, 発育環境が影響してい る例として, 同一の Genotype をもった近交系のマウス であっても, 母体の栄養障害 (ビタミン欠乏, または過 剩など）の程度によって, 生まれてくる子に奇形の発生 頻度が異なることがみられることがあげられよう。また， 動物の出生後に打いても, 親マウスの栄養的条件, 疾病 の有無, 動物の取扱いかたの適否は, 哺乳子マウスの発 育とも重要な関係がある.

一般に，動物実験成績とは，この表現型に直接加えら れた処置に対する反応である，と考党られがちであった。 しかし，遺伝子の作用と発育環境によって決定された， 同一の表現型を示す動物を, いくつかの異なった場所

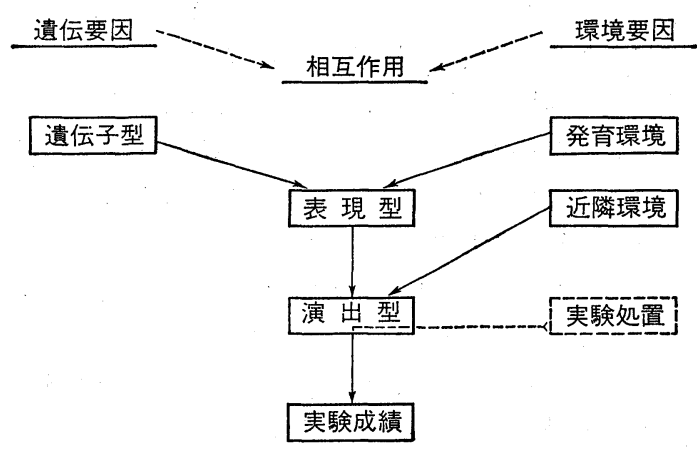

図 4 実験成樍に影響する遺伝要因と環境要因
（研究室）に移し，同一の実験処置を加えた場合に，必 ずしも同一の反応（すなわち実験成績）が得られない, といらことを, われわれは日常多く経験している.この ことの原因として，動物の蛙かれた近隣環境が影響して いるものと考只れる. 環境条件の違いによって, 動物 の生理状態は変化しやすいものであるので, 飼育環境条 件の違いによって, 動物の生理㙨能が亢進している状態 と，抑制されている状態とでは，たとえ同一処置を行な っても，実験成績が異なってくることは当然であろう。

以上のよらなことからみると, 動物実験を行ならさい の各種の環境条件, すなわち近隣環境 (Proximate environment) の影響を無視することができない。これらの 近隣環境諸因子の影響を考慮にいれて，ここに表現型に 抢ける永続的な生理機能とは異なった新しい概念を導入 する必要が生じてくる。すなわち, 表現型に近隣環境の 諸因子が作用して決定された “一時的な生理状態”を 「演出型 (Dramatype)」とよんでいる.そして, この演 出型に加党られた処置に刘する反応が，実際われわれが， 動物実験成續としてみているものである，と考光たほう が妥当であろう.

動物実験成績の判定のひとつが, 動物に現われる生理 的反応をみることである以上, 使われる動物相互の演出 型の均質性，すなわち “一時的な生理状態” の均質性と いうことが，重要な鍵となってくる．いいかえれば， “同一の実験使用する多数の動物は, 動物相互の生理 状態が可能なかぎり近似していること”が要求されるわ けである。そこで, 演出型の決定に関与する, 遣伝子型・ 発育環境・表現型・近隣環境が，それぞれ䈌しく規制さ れることが必要となる。

\section{4. おわりに}

適正な動物実験を行ならには，すず適正な動物の選択 が重要なことである. 適正な動物とは, 実験目的に合致 した遺伝的（動物種・系統など）特性をもち，実験目的 に合致した微生物（病原感染の有無・定着菌種など）統 御をうけ, 一定の望ましい環境で飼育された動物である といえよう。

次号以下, ひきつづいて, 動物実験に和ける遺伝・微 生物・環境要因などの影響について，具体的な例を示し つつ解説する予定である.

\section{文 献}

1) M.C. Green : Mutant Genes and Linkages. "Biology of the Laboratory Mouse", 2 nd ed., McGraw-Hill 
Book Co., N. Y., 1966, p. $87 \sim 150$.

2) V.W.Heine: Zur Planung von Einrichtungen für die Zucht und Haltung von Versuchstieren. Zschr. Versuchstierk., 5, 1〜20 (1964).

3）近藤恭司：シソポジウム記録，日本の実験動物の問題点. 1. 実験動物育種の立場から. 実験動物, 15, 71 76 (1966).

4）近藤恭司，汇崎 孝三郎，田嶋 嘉雄 : “実験動物関係用語 の定義—ICLA”についての邦訳ならびに解説. 実験 動物， 14，134 139 (1965).

5）日本医学会・動物実験現状調査会：動物実験の現状一 動物実験現状調査一 1960 一. 実験動物, 12, 27 35 (1963).

6）日本実験動物研究会：実験動物についての委員会；実験 動物の表示法のとりきめ（案） 1. マウスについて. 実
験動物, 12, 169 174 (1963).

7) T.Nomura and C. Yamauchi : Environments and Physiological Status of Experimental Animals. Experimental Animals in Cancer Research. "GANN Monograph”, Vol.5, Maruzen, Co., Tokyo, 1968, p. $17 \sim 36$.

8) W.M.S. Russell and R.L. Burch : "The Principle of Humane Experimental Technique”, Methuen \& Co. Ltd., London (1959).

9）田嶋嘉雄 : SPF 動物について. 実験動物, 13, 133 138 (1964).

10）田嶋嘉雄 : 実験動物について. 化学と生物, 3(8), 414 $\sim 418$ (1965).
私たちが叔いしいと感ずる食物の塩加減は，生理的 食塩水に近いといらが，昔から上方料理(京都，大阪) は薄味で, 江戸前料理は塩からいといわれる。はたし て実際にその食塩濃度はいかがなものかといらので， 私が母校に助手として残った年に, 両者の塩味の比較 研究を試みた。当時は平和なよき時代ではあったが， 簡単に上京して試料を入手するというのもままならぬ ことで，校長が出張上京される機会をねらい，蒐集用 のびんの持参を願って, 四季にわたり, 東京の有名料 理店の煮汁(吸物，みそ汁，煮物)を何回か持ち帰りい ただき，上方との比較を行なった．東京の物の官能テ ストは，現場でそのつど記入しておいてもらった．硝 酸銀液を用いての定量の結果は必ずしも江戸前の物が 濃くなくて, 官能テストの結果や言い慣わしと平行し なかった，私たらが実際に感ずる塩からさが，同時に 含まれる旨味成分や他の調味料に関係があったり, 温 度にも影響されることがわかった現在, 結果を振り返 えると，上方では，旨味成分を濃厚に含さだしを用い るなどして, 塩からさを強く感じさせないような, 含 みの多い料理の工夫がされていたのではないかとも思 われる。

炊饭に関しては本誌 Vol.6, No. 4 に松元文子先生 が述べられているし, 澱粉の研究にたずさわって抢ら れる方々も, 炊飯の定則といったような物を解明され ている.ところで, 炊飯 (米澱粉の糊化) には，一定 の水加減をして膨潤させた米を, $100^{\circ} \mathrm{C} て ゙ 20$ 分間加 熱することが不可欠の条件とされている. 近来普及し 始めた電子レンジは, 短時間加熱をその身上としてい るので, 炊飯などはもっての外といらことになるので あるが, 冒険的に, 加水量を多くして, 電子レンジに
よる炊飯を試み，官能テストをした結果は，ガス炊飯器 (電気炊飯器よりも一般に飯の炊さ上りがよいといわれ ている）によるものとの間に有意差を認めず, 澱粉の $\alpha$ 化率を測定した結果からも差を認めなかった。しかし， 炊いた飯を冷蔵庫に保存するという極端な条件での老化 を比較すれば, ガス炊飯器によるほうが老化が遅かった。 しかし，これとても，炊飯時に酵素を利用するなどの方 法で充分カバーできることを認めている.

先年, 乾燥鵎卵白の利用 価値についていろいろと実 験を行ない, その起泡につ いても試みたことがある。 元来, 卵白の泡は菓子や揚 物などの調理に貴重な補助 剂となるものであって，そ の泡の立ち具合や安定度が, 料理のできばえにかなり影 響する．英語の調理書では， cake に用いる場合の起泡 の程度を, 泡を泡立棒などで持ち上げたさいに peak が できて, その先端が折れ曲り, 泡の表面が wett である ことと表現している（peak のできないのはまだ立ら不 足，できた peak の先さが折れ曲らず, 表面が dry であ るのは立ちすぎといらわけである).この状態に立った とさの泡を顕微鏡で見れば，泡粒の大きさや粒ぞろいが わかり，また原料卵白に対する泡の容積増加率でも判定 できるわけであって，この瞬間の泡を安定にして（泡は そのまま放置すると変化しやすい) cake を焼けば，常 に焼上りのしっとりとした，おいしいものが造れるわけ である.もちろん, cake 材料の配合割合や oven の温 度などの影響も大きいが.なお, 卵白泡の安定性に対し て, 砂糖や酸が有効であることは周知のことと思う. 